Canadian Journal of Fisheries and Aquatic Sciences

Canadian Science Publishing Journal canadien des sciences halieutiques et aquatiques

\title{
Otolith chemistry and redistributions of northern cod: evidence of Smith Sound-Bonavista Corridor connectivity
}

\begin{tabular}{|r|l|}
\hline Journal: & Canadian Journal of Fisheries and Aquatic Sciences \\
\hline Manuscript ID & cjfas-2017-0357.R1 \\
\hline Danuscript Type: & Article \\
\hline Complete List of Authors: & $\begin{array}{l}\text { Neville, Victoria; Memorial University of Newfoundland, Biology } \\
\text { Rose, George; Memorial University of Newfoundland, Biology } \\
\text { Rowe, Sherrylynn; Memorial University of Newfoundland, Centre for } \\
\text { Fisheries Ecosystems Research } \\
\text { Jamieson, Robyn; Department of Fisheries and Oceans, } \\
\text { Piercey, Glenn; Memorial University of Newfoundland, Core Research } \\
\text { Equipment and Instrument Training Network }\end{array}$ \\
\hline $\begin{array}{r}\text { Is the invited manuscript for } \\
\text { consideration in a Special } \\
\text { Issue? : }\end{array}$ & N/A \\
\hline Keyword: & $\begin{array}{l}\text { ISOTOPES < General, OTOLITHS < General, WATER CHEMISTRY < } \\
\text { General, GADOID SPECIES < Organisms, MIGRATION < General }\end{array}$ \\
\hline \multicolumn{2}{|c}{} \\
\hline \multicolumn{2}{|c|}{}
\end{tabular}


2 Otolith chemistry and redistributions of northern cod: evidence of Smith Sound 3 Bonavista Corridor connectivity

4

5 Victoria Neville ${ }^{1}$, George Rose $e^{1,2,3}$, Sherrylynn Rowe ${ }^{1,4}$, Robyn Jamieson ${ }^{5}$ and Glenn Piercey ${ }^{6}$

$6{ }^{1}$ Department of Biology, Memorial University of Newfoundland, St. John's, NL A1B 3X9, 7 Canada.

$8 \quad{ }^{2}$ NSERC Chair in Fisheries Conservation, Memorial University of Newfoundland, St. John's, 9 NL A1C 5R3, Canada

$10{ }^{3}$ Institute for the Oceans and Fisheries, University of British Columbia, Vancouver, BC V6T 11 1Z4, Canada.

$12{ }^{4}$ Centre for Fisheries Ecosystems Research, Fisheries and Marine Institute, Memorial University 13 of Newfoundland, St. John's, NL A1C 5R3, Canada.

$14{ }^{5}$ Department of Fisheries and Oceans, PO Box 5667, St. John's, NL A1C 5X1, Canada.

$15{ }^{6}$ Core Research Equipment and Instrument Training Network (CREAIT), Bruneau Centre for

16 Research and Innovation, Memorial University of Newfoundland, St. John's, NL A1C 5S7, 17 Canada.

18 Corresponding author: vk.neville@ mun.ca

Keywords: Stable oxygen isotopes, Atlantic cod, otolith chemistry, migration, isoscapes

23 Stable oxygen isotope assays of otoliths $\left(\delta^{18} \mathrm{O}_{\text {oto }}\right)$ from migrant Atlantic cod (Gadus morhua) that

24 overwintered in Smith Sound, Newfoundland during 1995-2006 differed from those of non-

25 migrating summer residents and cod from Placentia Bay and Halibut Channel, but did not differ

26 from those of cod from the adjacent offshore Bonavista Corridor in summer. All fish sampled

27 were of the 1990-year class (founder of the Smith Sound aggregation) at ages 8-10 years. Hence,

28 overwintering Smith Sound and summering Bonavista Corridor cod likely experienced similar

29 temperatures and salinities in each year of life, representing different migration stages of an 
30 intermixed group. Moreover, predictions of $\delta^{18} \mathrm{O}_{\text {oto }}$ from near-bottom ocean temperatures and

31 salinities differed between inshore and offshore sites and in general matched observed signatures

32 of inshore and offshore cod. The Bonavista Corridor cod, however, were an exception, having

$33 \delta^{18} \mathrm{O}_{\text {oto }}$ signatures suggestive of inshore exposure. Our findings provide direct evidence of

34 metapopulation structure in the Northern cod and are consistent with offshore rebuilding having

35 been spurred by dispersal of cod from inshore Smith Sound.

\section{Introduction}

38 The historic range of the "Northern" cod (Gadus morhua) stock extended from the Hamilton

39 Bank region off Labrador, Canada, to the northern Grand Bank occupying Northwest Atlantic

40 Fisheries Organization (NAFO) Divisions 2J3KL (Fig. 1). Long recognized as a stock complex

41 (Lear 1986), the largest components overwintered and spawned offshore in warm $\left(\sim 2-4^{\circ} \mathrm{C}\right)$ water

42 on the continental shelf and slope (Templeman 1962; Fitzpatrick and Miller 1979; Hutchings et

43 al. 1993). In spring, cod migrated inshore to feed, primarily on capelin, utilizing several deep

44 channels that undercut the outer parts of the cold Labrador Current (Lear 1984; Rose 1993). The

45 stock complex also included smaller groups of inshore residents that overwintered and spawned

46 in the colder (at times sub-zero) coastal habitats in winter, spring and early summer (Templeman

47 and Fleming 1956; Goddard et al. 1994; Wroblewski et al. 1995; Smedbol and Wroblewski

48 1997; Rose et al. 2011).

49

50 The collapse of Northern cod in the early 1990s coincided with substantial distributional changes

51 (deYoung and Rose 1993; Atkinson et al. 1997; Rose et al. 2000; Ruzzante et al. 2001). In the

52 offshore, cod "hyper-aggregated" in large shoals in their southernmost migration channel, the 
53 Bonavista Corridor, as the stock declined (Rose 1993; Rose and Kulka 1999). By 1993, few cod

54 remained there (Rose et al. 1994), and by 1994, few were evident anywhere within the former

55 Northern cod offshore range (Bishop et al. 1995; Rose 2007).

57 In the spring of 1995, with offshore components of the Northern cod at their lowest levels in

58 recorded history (Bishop et al. 1995), a relatively large aggregation (10,000 $t$ ) appeared inshore

59 in Smith Sound, Trinity Bay, a fjord adjacent to the Bonavista Corridor (Rose 2003; Rose et al.

60 2011). The majority of individuals in this aggregation were 5 years old (1990-year class),

61 accompanied by some 6-year-olds (1989 year-class), and were likely first-time spawners. By

62 early that summer, most had migrated out of Smith Sound, but they returned each fall for the

63 next decade to overwinter. They spawned both there and during the early phases of the outward

64 migration from Smith Sound (Brattey and Healey 2007; Knickle and Rose 2010; Rose et al.

65 2011). Smith Sound historically maintained a relatively small number of resident cod year-

66 around, but the overwintering of a large migratory aggregation was unprecedented (Rose et al.

67 2011). The aggregation grew to $>25,000 \mathrm{t}$ by the early 2000s but beginning in 2007 a sharp

68 decline occurred in overwintering biomass (Rose et al. 2011). By 2009, there was little evidence

69 of the overwintering aggregation and it was assumed that the fish had largely dispersed (Brattey

70 et al. 2010; Rose et al. 2011).

71

72 The rise and fall of the Smith Sound cod was attributed not to an event isolated from adjacent

73 groups, but to metapopulation dynamics (Rose et al. 2011). In keeping with this notion, the

74 offshore trawl survey conducted by Department of Fisheries and Oceans Canada (DFO) showed

75 unexpected and difficult to explain increases in some year classes during the time the Smith 
76 Sound cod dispersed. Potential links between Smith Sound cod and those inhabiting the offshore

77 were further supported by improvements in the fit of stock assessment models that included the

78 Smith Sound cod as a component of the full Northern cod stock not surveyed by the offshore

79 survey (Cadigan 2016). The improved model fit assumed a lower catchability (q) for the offshore

80 survey until the Smith Sound cod rejoined the offshore. It was apparent, nonetheless, that direct

81 evidence of links between the Smith Sound cod and those from offshore regions was lacking

82 (Rose et al. 2011; Rose and Rowe 2015). As the Northern cod stock rebuilds, connections among

83 inshore and offshore stock components are not yet fully understood. A key question is whether

84 the rebuilding of Northern cod is solely a product of isolated local population growth, or have

85 spatial redistributions within a metapopulation played a role (Rose and Rowe 2015)?

87 Stable oxygen isotope $\left(\delta^{18} \mathrm{O}\right)$ signatures in otoliths (hereinafter $\delta^{18} \mathrm{O}_{\text {oto }}$ ) reflect past ambient

88 environmental conditions (specifically seawater salinity and temperature) and hence have

89 potential to identify annual and seasonal habitats of individuals, when past conditions can be

90 mapped. Notably, $\delta^{18} \mathrm{O}_{\text {oto }}$ has been used to identify habitat changes spanning life stages (Gao and

91 Beamish 2003, Gao et al. 2004, Shephard et al. 2007) and seasons (Weidman and Millner 2000;

92 Gao et al. 2001; Begg and Weidman 2001; Høie and Folkvord 2006). Here, we postulated that

$93 \delta^{18} \mathrm{O}_{\text {oto }}$ signatures of cod from the Smith Sound overwintering aggregation and summer residents

94 would differ, and furthermore, that if overwintering Smith Sound cod had non-local origin, their

95 signatures should be similar, at least in their early years, to cod from a remote site.

96

97 In this study, we used $\delta^{18} \mathrm{O}_{\text {oto }}$ signatures to test these hypotheses on the origins of the Smith

98 Sound cod and putative connection with the adjacent offshore Bonavista Corridor and other 
99 remote sites. Specifically, we compared the $\delta^{18} \mathrm{O}_{\text {oto }}$ signatures from cod otoliths from the 1990

100 founder year-class collected from the winter aggregation with those from the same year-class

101 that remained as summer residents and thought to possibly represent a different ecotype

102 (subgroup that is especially adapted to a particular set of environmental conditions) with

103 different life history and origin. We then hypothesized that the Smith Sound overwintering and

104 Bonavista Corridor summering cod had a similar origin and distributional history over their life,

105 their $\delta^{18} \mathrm{O}_{\text {oto }}$ signatures would be similar, but differ from those from the Halibut Channel and

106 Placentia Bay (Fig. 1). To ensure that isotopic signatures of the sites would be distinguishable,

107 ambient ocean $\delta^{18} \mathrm{O}_{\text {oto }}$ was predicted using available salinity and temperature data for each area

108 (Fig. 2; Fig, 4). We later compared our predicted $\delta^{18} \mathrm{O}_{\text {oto }}$ with the signatures measured in the cod

109 otoliths.

\section{Methods}

\section{Otolith collection}

113 Cod were collected during research cruises (CCGS Teleost) conducted during 1998-2000, with

114 the exception of otoliths from Halibut Channel, which were provided by Fisheries and Oceans

115 Canada, Northwest Atlantic Fisheries Centre, St. John's (Table 1). In Smith Sound, otoliths that

116 were taken from cod caught in January from the main aggregation were most likely those of

117 overwintering migrants, whereas cod caught in June of the same year-class, after the aggregation

118 had migrated beyond the Smith Sound, were more widely dispersed within Smith Sound and will

119 be referred to as residents. In all other regions, cod were caught between May and July from

120 spawning and post-spawning aggregations. In all cases, otoliths were extracted from sampled

121 cod, dried and stored in envelopes. 
123 Initial ageing was conducted by microscopic examination of the annuli (paired translucent and

124 opaque bands) of right-side otoliths that were cracked and examined by an experienced

125 technician (Norm Batten, former chief ageing technician with Fisheries and Oceans Canada,

126 Northwest Atlantic Fisheries Centre, St. John's). Right otolith age data were used to identify age-

127 and year class information for the sample. For this study, otoliths from a selection of cod (chosen

128 haphazardly based on availability) from the 1990-year class were analyzed (Table 1).

130 To test if overwintering and resident cod had differing growth patterns, as might be expected if

131 these groups had differing ranges or migratory habits, lengths of aged cod caught with a

132 Campelen 1800 bottom trawl fished from the RV Teleost in winter and summer in Smith Sound

133 from 1996 to 2003 were compared. von Bertalanffy curves (using nonlinear least squares

134 regression) were fit for each group. Using the estimated parameters from these curves we back-

135 calculated length-at-age and tested whether the products of these calculations were different at

136 each age using a Welch's two sample t-test. First, we treated age as a categorical variable, from

137 1-10. However, this method may have been confounded by the fact that Smith Sound migrants

138 (collected in January-February) were approximately 6 months younger than Smith Sound

139 residents (collected in June). To explore an approximation to the extent of size differences

140 between these groups, we subsequently corrected the age data by accounting for the true age

141 (Year + \# of days/365) of individuals. We re-ran the analysis with the age of the fish converted

142 to a decimal age (i.e. 1.43 years old) while assuming a birthdate of 01/Jan.

\section{Otolith preparation and analysis}


145 Prior to $\delta^{18} \mathrm{O}_{\text {oto }}$ analysis, intact left otoliths were rinsed with distilled water and $70 \%$ ethanol,

146 embedded in hard epoxy resin, and sectioned using an IsoMet Low Speed saw (Buehler Canada,

147 Whitby, Ontario). To collect a $1 \mathrm{~mm}$ otolith section, the saw was mounted with two IsoMet

148 diamond wafering blades (Beuhler, Illinois USA) separated by a $1 \mathrm{~mm}$ metal spacer. To ensure

149 that the section contained all annuli from the previously determined age, it was examined under

150 an Olympus SZY16 (Olympus America INC, Pennsylvania, USA) stereoscope in a Petri dish of

$15170 \%$ ethanol, and digitally imaged with cellSens imaging software (Olympus America INC,

152 Pennsylvania, USA). The images were enhanced for contrast using Photoshop (Adobe).

153 The section image was examined to identify areas on the otolith to be sampled. Two samples per

154 annulus were collected: one opaque sample and one translucent sample comprising sixteen

155 samples of otolith material for an eight-year-old cod. Opaque regions of the otolith annuli are

156 thick, appear light-coloured under reflected light, and sometimes considered to be the "summer

157 band". The opaque rings are broken up by thinner translucent bands that appear dark under

158 reflected light and are sometimes referred to as "winter bands." An automated MicroMill (New

159 Wave Research INC, California, USA) equipped with a $480 \mu \mathrm{m}$ diameter tungsten bit was used

160 to mill otoliths at the identified sample sites to a depth of $150 \mu \mathrm{m}$.

162 The drill bit was wider than the otolith bands being sampled, hence except for the first annulus

163 removal of discrete samples required that sample paths were milled by running the drillbit along

164 the edge of the otolith bands following the method of Wurster et al. (1999). Each milled sample

165 of otolith powder was tapped into a separate decontaminated EXETAINER® vial (@ Labco

166 Limited). Samples were analyzed for stable oxygen isotope ratio on an isotope ratio mass

167 spectrometer (IRMS) using a GasBench II in stable isotope laboratories at Memorial University 
168 (Delta V Plus) and the University of Arkansas (Delta Plus). Stable oxygen isotope values were

169 reported in $\delta$ notation relative to the Vienna Pee Dee Belemnite (VPDB) international standard:

171 Eq 1

$$
\delta^{18} \mathrm{O}=\left(\frac{\mathrm{R}_{\text {sample }}-\mathrm{R}_{\text {standard }}}{\mathrm{R}_{\text {standard }}}-1\right) \times 1000(\% 0)
$$

172 where $\mathrm{R}$ is the ratio of heavy and light isotopes $\left({ }^{18} \mathrm{O}:{ }^{16} \mathrm{O}\right)$ in the sample or standard and values

173 are expressed in per mil (\%o) units.

174 After several batches of samples had been assayed, it was observed that the quality of the $\delta^{18} \mathrm{O}_{\text {oto }}$

175 sample signal precision began to deteriorate when minute amounts of material were assayed on

176 the IRMS. Specifically, measurements of $\delta^{18} \mathrm{O}_{\text {oto }}$ began to drift when the amount of material

177 assayed produced peaks with an area of less than $2.5 \mathrm{Vs}$ (volts seconds). To ensure best results

178 with minute amounts of material, following the method of Breitenbach and Bernasconi (2011),

179 we proceeded to use smaller EXETAINER ${ }^{\circledR}$ vials $(4.5 \mathrm{~mL})$ than the customary $(12 \mathrm{~mL})$ ones

180 that had initially been used in this study. The use of smaller vials with decreased headspace

181 enabled smaller samples (range: $10-30 \mu \mathrm{g}$ ) to be analyzed using the GasBench II preparation

182 device and significantly improved the quality of data collected. As a result of this issue, all

183 values below the $2.5 \mathrm{Vs}$ threshold (which reflected failed assays) were removed prior to

184 statistical analysis.

186 Environmental data

187 Interpretation of $\delta^{18} \mathrm{O}_{\text {oto }}$ data requires knowledge of the ambient isotopic landscape (or

188 "isoscape"; Bowen (2010), Hobson et al. (2010)) of $\delta^{18} \mathrm{O}$ where the fish live and factors that

189 influence the uptake of isotope signatures into otoliths (fractionation). Oxygen isotope ratios of 
190 seawater $\left(\delta^{18} \mathrm{O}_{\text {sw }}\right)$ are positively correlated with salinity (Epstein and Mayeda 1953; Craig and 191 Gordon 1965; Tan and Strain 1988; Jamieson 2001) and have been extensively surveyed on the 192 Newfoundland and Labrador shelf (Jamieson 2001). Hence, $\delta^{18} \mathrm{O}_{\mathrm{sw}}$ can be mapped in marine 193 areas where salinities are known. Fractionation of oxygen to otolith from seawater however 194 occurs as an inverse function of ambient temperature (Kalish 1991; Høie et al. 2004; Geffen 1952012 ; Stanley et al. 2015,2016 ). Consequently, $\delta^{18} \mathrm{O}_{\text {oto }}$ is the product of environmental $\delta^{18} \mathrm{O}_{\mathrm{sw}}$ 196 combined with the effect of temperature fractionation (i.e., a $1^{\circ} \mathrm{C}$ temperature adjustment results 197 in a change of $-0.2 \%$ in $\delta^{18} \mathrm{O}_{\text {oto }}$ where an adjustment in salinity of 1 will result in a change of $198+0.62 \% \delta^{18} \mathrm{O}_{\text {oto }} ;$ Jamieson (2001)).

200 Measured $\delta^{18} O_{s w}$

201 Oceanic $\delta^{18} \mathrm{O}_{\mathrm{sw}}$ data from Jamieson (2001) were collected during an extensive April-July 1998

202 survey of the spatial variation in $\delta^{18} \mathrm{O}_{\mathrm{sw}}$ across the Newfoundland and Labrador shelf. These data 203 were used to construct a map of real $\delta^{18} \mathrm{O}_{\mathrm{sw}}$ values (Fig. 1) which aided in the interpretation of $204 \delta^{18} \mathrm{O}_{\text {oto }}$ in this study. Only data from the deepest water sample at each location were extracted for 205 this purpose as these were thought to best represent ambient bottom conditions experienced by $206 \operatorname{cod}($ mean \pm s.d.; $175.70 \mathrm{~m} \pm 142.3$ ). There is likely some uncertainty introduced with this 207 assumption, particularly during spring when cod can undertake extensive vertical migrations (see 208 Rose 2003; 2009; Rose and Rowe 2015) and also as seawater was sampled in April-July only.

209 Water samples were collected alongside temperature and salinity measurements using a rosette 210 sampler fitted with a conductivity, temperature, and depth (CTD) recorder on a Fisheries and 211 Oceans Canada oceanographic survey. In relevant areas where $\delta^{18} \mathrm{O}_{\mathrm{sw}}$ data were not available 
212 from Jamieson (2001), the data were extracted from Tan and Strain (1988) (Accessed from the

213 Global Seawater Oxygen-18 Database http://data.giss.nasa.gov/o18data/).

214

215 Predicted $\delta^{18} O_{\text {oto }}$

216 The oceanic $\delta^{18} \mathrm{O}_{\mathrm{sw}}$ data from Jamieson (2001) and Tan and Strain (1988) illustrate the onshore-

217 offshore trends in $\delta^{18} \mathrm{O}_{\text {sw }}$ but do not predict $\delta^{18} \mathrm{O}_{\text {oto }}$ for the collection locations in this study. To

218 predict $\delta^{18} \mathrm{O}_{\text {oto }}$ values for cod from each area, temperature and salinity data from the Marine

219 Environmental Data Service (MEDS) Canada were used. Only CTD data from the deepest $5 \mathrm{~m}$

220 sampled at each location (mean \pm s.d.;182.0m \pm 139.8 ) were assessed. $\delta^{18} \mathrm{O}_{\text {sw }}$ was predicted

221 using the linear relationship with salinity reported by Jamieson (2001) and salinity records from

222 MEDS (Fig. 2; Fig 3).

223

224 Eq 2.

Predicted $\delta^{18} \mathrm{O}_{\mathrm{sw}}=0.65$ (Salinity) -22.61

225 This equation calculated predicted $\delta^{18} \mathrm{O}_{\mathrm{sw}}$ relative to Vienna Standard Mean Ocean

226 Water (VSMOW). Subsequently, we converted the predicted $\delta^{18} \mathrm{O}_{\text {sw }}$ from VSMOW to the

227 Vienna Pee Dee Belemnite (VPDB) carbonate standard (appropriate for otoliths) using the

228 following conversion (Coplen 1995).

229 Eq $3 . \quad \delta^{18} \mathrm{O}$ VPDB $=\delta^{18} \mathrm{O} \operatorname{VSMOW}(0.97006)-29.94$

230 Lastly, the predicted $\delta^{18} \mathrm{O}_{\text {oto }}$ was calculated using the predicted $\delta^{18} \mathrm{O}_{\mathrm{sw}}$ with the temperature data

231 from MEDS using a temperature-dependent fractionation equation for cod (Høie et al. 2004)

232 Eq. $4 \quad 1000 \operatorname{Ln} \alpha=16.75\left(\frac{1000}{\mathrm{~T}}\right)-27.09$ 


\section{Statistical analysis}

235 To investigate the origin of the Smith Sound overwintering aggregation, a linear model was 236 applied to test the null hypothesis of no difference in $\delta^{18} \mathrm{O}_{\text {oto }}$ between cod collected in Smith

237 Sound during winter and those from four potential origin sites (Smith Sound (during summer),

238 Halibut Channel, Placentia Bay and Bonavista Corridor) for each annulus.

240 Eq 5.

$$
\delta^{18} \mathrm{O}_{\mathrm{oto}}[\mathrm{ann}]=\beta \mathrm{o}+\beta_{\mathrm{Site}} * \text { Site }+\beta_{\text {Season } * \text { Season }+\varepsilon}
$$

241 Where, $\delta^{18} \mathrm{O}_{\text {oto }}$ is the oxygen isotope ratio of otolith carbonate, ann is the annulus number, Site is

242 the collection site of the fish (a categorical explanatory variable), Season is the translucent or

243 opaque band of the fish (a categorical explanatory variable) and $\varepsilon$ is residual. This test was

244 repeated for each annulus. Pair-wise comparisons were calculated using Tukey's post-hoc range

245 tests. All analyses were undertaken in R (R Core Team 2014).

\section{Results}

\section{Otolith isotopes}

248 For the 87 cod otoliths used in this study, 1423 micromilled powder samples were assayed on the

249 IRMS. Of these, 1095 samples $(77 \%)$ satisfied the peak area threshold of $2.5 \mathrm{Vs} . \delta^{18} \mathrm{O}_{\text {oto }}$ was

250 typically, lowest in the first annulus and increased in subsequent annuli (Fig. 4). Differences in

$251 \delta^{18} \mathrm{O}_{\text {oto }}$ between adjacent opaque and translucent bands were small $(\mathrm{p}>0.05)$ compared to among

252 site differences and the ontogenetic trend within otoliths. This effect of season (or difference

253 between translucent and opaque bands) on $\delta^{18} \mathrm{O}_{\text {oto }}$ was not significant for any annuli ( $\mathrm{p}$ 's $>0.05$ ) 
254 and was removed from further analyses. The reduced model indicated that collection site had a 255 significant effect on $\delta^{18} \mathrm{O}_{\text {oto }}$ for all annuli $(\mathrm{p}<0.001)$.

257 Smith Sound overwintering and resident cod

258 The $\delta^{18} \mathrm{O}_{\text {oto }}$ of overwintering and resident cod in Smith Sound differed significantly in annuli 1, 259 4, 6, 7, and 8 (Fig. 4a; Table 2). Cod sampled in winter (January-February) from the 260 overwintering aggregation were significantly $(\mathrm{p}<0.001)$ larger at all ages than resident cod 261 sampled in June (Fig. 5). These differences were highly significant $(\mathrm{p}<0.001)$ when age was 262 treated categorically; Smith Sound Winter migrants were $\sim 2 \mathrm{~cm}$ larger at all ages (except for age 263 1; Fig. 5a). Further, when the age data was corrected to include decimal years, the discrepancies 264 between the Smith Sound migrants and residents increased ( $\sim 5.4 \mathrm{~cm}, \mathrm{p}<0.001$; Fig. 5b). 265

266 Predictions of $\delta^{18} \mathrm{O}_{\text {oto }}$ from the temperature and salinity data from the Smith Sound area were 267 lower than the predictions for offshore sites (Bonavista Corridor, Halibut Channel; Fig. 3). In 268 general, the measured $\delta^{18} \mathrm{O}_{\text {oto }}$ for Smith Sound residents and migrants were consistent with 269 predictions of lower $\delta^{18} \mathrm{O}_{\text {oto }}$ for Smith Sound and Bonavista Corridor.

271 The $\delta^{18} \mathrm{O}_{\text {oto }}$ of Bonavista Corridor cod and resident Smith Sound cod differed significantly in 272 annuli 1, 6, 7 and 8 (Fig. 4j; Table 2). In contrast, there was no significant difference between $273 \delta^{18} \mathrm{O}_{\text {oto }}$ in any annuli, of cod overwintering in Smith Sound and sampled in summer in the 274 Bonavista Corridor (Fig. 4; Table 2).

275

\section{Halibut Channel}


277 The $\delta^{18} \mathrm{O}_{\text {oto }}$ signatures of cod collected in Halibut Channel were higher than those of any other 278 group (Fig. 4; Table 2) except for annulus 1, which was depleted relative to other annuli and not 279 significantly different from annulus 1 from resident Smith Sound cod (Fig. 4f, h; Table 2). The 280 higher $\delta^{18} \mathrm{O}_{\text {oto }}$ signatures for otoliths from cod in the Halibut Channel were consistent with the 281 higher $\delta^{18} \mathrm{O}_{\mathrm{sw}}$ of the collection site (Fig. 3).

282

283 Placentia Bay

284 The $\delta^{18} \mathrm{O}_{\text {oto }}$ signatures of otoliths from cod collected in Placentia Bay did not differ significantly 285 from those of Smith Sound residents (Fig 4e, Table 2). No consistent patterns of similarity were 286 evident among the $\delta^{18} \mathrm{O}_{\text {oto }}$ signatures of cod from Placentia Bay and other sites, although some 287 similarities existed. The Placentia Bay cod shared similar $\delta^{18} \mathrm{O}_{\text {oto }}$ signatures with cod 288 overwintering in Smith Sound at annuli 3 and 5, and summering in the Bonavista Corridor at 289 annuli 1, 2, 3 and 4 (Fig. 4, Table 2)

290

291 Seawater $\delta^{18} O$

292 All available data on bottom $\delta^{18} \mathrm{O}_{\text {sw }}$ from waters around Newfoundland and Labrador indicated 293 that low salinity and lower $\delta^{18} \mathrm{O}_{\mathrm{sw}}$ were prevalent in most inshore regions, with both variables 294 increasing with depth toward the offshore (Fig. 1).

296 Predicted $\delta^{18} O_{\text {oto }}$

297 Predicted $\delta^{18} \mathrm{O}_{\text {oto }}$ for each of the origin sites based on ambient temperature and salinity in each 298 area reflected the inshore-offshore trend shown in measured $\delta^{18} \mathrm{O}_{\mathrm{sw}}$ (Fig. 1). The offshore sites 299 Bonavista Corridor and Halibut Channel had the highest predicted $\delta^{18} \mathrm{O}_{\text {oto }}$ values, with Halibut 
300 Channel predicted $\delta^{18} \mathrm{O}_{\text {oto }}$ slightly lower than for the Bonavista Corridor (Fig. 3). By comparison, 301 predicted $\delta^{18} \mathrm{O}_{\text {oto }}$ for the inshore sites Smith Sound and Placentia Bay were 50\% lower than for

302 the offshore sites. In general, the measured $\delta^{18} \mathrm{O}_{\text {oto }}$ signatures were congruent with predictions,

303 with the exception of Bonavista Corridor. For this area, observed $\delta^{18} \mathrm{O}_{\text {oto }}$ were less than predicted

$304 \delta^{18} \mathrm{O}_{\text {oto }}$ for this offshore region and similar to predictions and observations for inshore areas.

306 Discussion

307 Bonavista Corridor - Smith Sound connection

308 The results of these otolith assays indicated that cod from the overwintering aggregation in Smith

309 Sound had $\delta^{18} \mathrm{O}_{\text {oto }}$ signatures that were virtually identical to those of the same year-class in the

310 Bonavista Corridor in summer (Fig. 4a). These near-identical $\delta^{18} \mathrm{O}_{\text {oto }}$ signatures held for each

311 year from age 1 (1990) to age 8 (1998), including the 5 years prior to the onset of the aggregation

312 in Smith Sound in 1995. This result suggests that these cod inhabited similar environments from

313 age 1 onward. Furthermore, the low $\delta^{18} \mathrm{O}_{\text {oto }}(\sim 1.5 \%$ VPDB $)$ suggests that the juvenile habitat

314 was largely inshore. The increase in $\delta^{18} \mathrm{O}_{\text {oto }}$ up to age 5 with relative stability at older ages is

315 consistent with known ontogenic changes of range with age. Northern cod juveniles (1-3) are

316 relatively sedentary in inshore habitats with gradual range and depth increases until a year before

317 maturation (age 4-5) when adult migratory behaviour and range become apparent (Anderson and

318 Dalley 1997). The source of new recruits to Smith Sound and the Bonavista Corridor from 1995-

3192007 is not known, although Anderson and Rose (2001) linked spawning further north to

320 widespread juvenile presence across much of the Newfoundland Shelf. Knickle and Rose (2010)

321 found that Smith Sound larvae were both retained and subject to drift outside the Sound. The

322 present results indicate that the most likely source of the 1990 year-class, the key founder of the 
323 Smith Sound cod, was the major spawning that occurred in the Bonavista Corridor in 1990 (Rose 324 1993).

326 Conventional tagging studies had previously demonstrated that migration of cod from Smith 327 Sound in spring occurred mostly to the north along the coast, but lack of fishing effort precluded 328 any knowledge of potential offshore movements (Brattey 2000). Telemetry studies tracked large $329 \operatorname{cod}(>65 \mathrm{~cm})$ solely along the shore (Brattey 2000). Notably, when cod were tagged in the 330 Bonavista Corridor in late winter of 2007 and 2008, there were many captures inshore (Brattey et 331 al. 2010). The present results suggest that the connection between the Smith Sound and 332 Bonavista Corridor cod occurred much farther back, to the founding year-class. Our data suggest 333 that overwintering cod in Smith Sound and those of the same year class in summer in the 334 Bonavista Corridor represented different migration stages of the same group. The $\delta^{18} \mathrm{O}_{\text {oto }}$

335 signatures of both stages were lower than those from the Halibut Channel, cod not thought to 336 migrate inshore (Healey et al. 2014), despite the Bonavista Corridor site having higher predicted 337 environmental $\delta^{18} \mathrm{O}_{\text {oto }}$ based on temperature and salinity data (Fig 3). The Bonavista Corridor 338 and the adjacent slope waters have relatively stable temperatures $\left(2-4^{\circ} \mathrm{C}\right)$ and high salinity $(33-$

339 34) compared to the inshore, including Smith Sound. The high salinity of the deep Bonavista

340 Corridor area drives the prediction of high $\delta^{18} \mathrm{O}_{\text {oto }}$. That the Bonavista Corridor and

341 overwintering Smith Sound signatures were more consistent with lower predicted $\delta^{18} \mathrm{O}_{\text {oto }}$ for the

342 inshore, and more closely matched the $\delta^{18} \mathrm{O}_{\text {oto }}$ values of cod from the inshore sites (Placentia Bay

343 and Smith Sound residents), suggests that these cod were spending most the year inshore with

344 excursions to the offshore. Vertical movements of migrating cod in spring into the fresher and

345 colder waters of the Labrador Current (Rose 1993, Rose and Rowe 2015) would also lead to 
346 lowered $\delta^{18} \mathrm{O}_{\text {oto }}$ isotope signatures (it was not feasible to take this into account in the present

347 predictions of ambient conditions).

349 The averaging of translucent and opaque otolith band samples may have contributed to the

350 lack of seasonal differences in $\delta^{18} \mathrm{O}_{\text {oto. }}$. Translucent otolith bands are much thinner than opaque

351 bands, hence translucent samples were often contaminated with nearly equal parts adjacent

352 opaque material, and this reduced potential detection of seasonal differences (Høie et al. 2004;

353 Kastelle et al. 2014; Kastelle et al .2017), and hence the ability to detect seasonal migrations.

354 Secondary Ion Mass Spectrometry enables higher resolution sampling and is suggested as a way

355 to better detect seasonal differences within the otolith (Matta et al. 2013; Darnaude et al. 2014).

357 Overwintering Smith Sound cod not only had different $\delta^{18} \mathrm{O}_{\text {oto }}$ signatures than residents but were

358 significantly larger $(\mathrm{p}<0.001)$. It is noteworthy that the Smith Sound overwintering cod were

359 actually $\sim 6$ months younger (when sampled in January-February) than summer residents

360 sampled in June, yet the size differences were still apparent. Seasonally adjusted discrepancies

361 between migrants and residents in Smith Sound increased to $\sim 5.4 \mathrm{~cm}$ at all ages $(\mathrm{p}<0.001$; Fig.

$3625 b)$. Size discrepancies between these groups are consistent with migrants and residents being

363 different ecotypes (Bardarson et al. 2017) occupying different habitats as they mature and likely

364 utilizing different food sources for at least part of the year.

366 Given similar thermal regimes, migrating cod are likely to have higher growth rates than

367 residents because they access better feeding conditions when they migrate from the

368 overwintering-spawning area (Rose et al. 1994; Atkinson and Sibly 1997). Although the thermal 
369 environments of the sampled cod are not known, migrating offshore in summer would likely lead

370 to a colder not warmer environment than inshore, and hence poorer growth. However, in the

371 years in question, capelin migration from offshore to coastal spawning locations was much

372 delayed from historical norms (Nakashima and Wheeler 2002), and most capelin would have

373 been offshore in June. This differs from historical behaviour, when capelin onshore migration

374 would have been well underway by June. Hence, a possible explanation for cod moving offshore

375 after spawning and into colder waters may be the location of key prey, especially capelin, the

376 historical motivation for the post-spawning migration (Rose et al. 2011). If correct, these cod

377 would have come back inshore in July or August with the late spawning capelin. This hypothesis

378 is consistent with lower $\delta^{18} \mathrm{O}_{\text {oto }}$ signatures than would be predicted by offshore residence.

380 The closely matching $\delta^{18} \mathrm{O}_{\text {oto }}$ signatures from overwintering Smith Sound and Bonavista

381 Corridor cod differed significantly from those of cod collected at other potential origin sites -

382 including resident Smith Sound cod. The difference between the overwintering Smith Sound cod

383 and those from Halibut Channel and Placentia Bay was not unexpected, as these fish would

384 almost certainly have experienced very different oceanographic (temperature and salinity)

385 conditions.

387 Cod captured in Placentia Bay in summer had $\delta^{18} \mathrm{O}_{\text {oto }}$ signatures similar to those of Smith Sound

388 residents. Cod are known to spawn in inner Placentia Bay where these cod were captured

389 (Lawson and Rose 2000). Placentia Bay and Smith Sound are separated by only a small isthmus

390 (Fig. 1) and have strong and similar freshwater inputs from adjacent regions; hence the similarity

391 of their inshore signatures was not unexpected. Both inshore groups had $\delta^{18} \mathrm{O}_{\text {oto }}$ signatures that 
392 were lower than Halibut Channel cod that were unlikely to have migrated inshore based on

393 tagging studies (Healey et al. 2014). It remains unexplained, nonetheless, that both of these

394 inshore groups had $\delta^{18} \mathrm{O}_{\text {oto }}$ signatures that were generally higher than those of the overwintering

395 cod in Smith Sound. It might have been expected that inshore residents would exhibit not only

396 different signatures from migrants, as observed, but at lower not higher $\delta^{18} \mathrm{O}_{\text {oto. }}$ Increased sea

397 temperatures result in lower $\delta^{18} \mathrm{O}_{\text {oto }}$ as a consequence of temperature-dependant fractionation and

398 year-round residency inshore would almost certainly lead to higher ambient temperatures during

399 the main growth period of summer and fall in this stock, relative to fish that migrated to offshore

400 waters influenced by the cold Labrador Current. This hypothesis might explain

401 the elevated $\delta^{18} \mathrm{O}_{\text {oto }}$ signatures of inshore cod, but requires further investigation.

402

403 The predicted isoscape was generally consistent with observed cod $\delta^{18} \mathrm{O}_{\text {oto }}$ measurements, with

$404 \delta^{18} \mathrm{O}_{\text {oto }}$ signatures lower inshore than offshore, based on the Halibut Channel cod being the

405 the offshore out-group. These fish had high observed $\delta^{18} \mathrm{O}_{\text {oto }}$ signatures at all ages (except age 1)

406 that were highly congruent with predicted $\delta^{18} \mathrm{O}_{\text {oto }}$ based on ambient salinity and temperature

407 data. In agreement with tagging studies, there was little isotopic evidence of inshore migration

408 from this site to environments with lower ambient $\delta^{18} \mathrm{O}_{\text {oto }}$ (Healey et al. 2014). Despite this,

409 slight offsets (small compared to differences among groups) were evident between predicted and

410 observed $\delta^{18} \mathrm{O}_{\text {oto. }}$ Offsets were also reported in a study of plaice (Pleuronectes platessa) in the

411 North Sea, in which a hydrographic model was applied to the predictions of $\delta^{18} \mathrm{O}_{\text {oto }}$ (Darnaude et

412 al. 2014). Offsets could be caused by vital (physiological) effects, species specific fractionation

413 or salinity correlation inaccuracies. 
415 Finally, the lowest $\delta^{18} \mathrm{O}_{\text {oto }}$ signatures were commonly observed in the first annulus of the otolith.

416 Two possible scenarios might explain this. Firstly, cod likely occupied shallow nearshore

417 areas at ages 0-1, specifically eel grass (Zostera marina) beds (Gotceitas et al. 1997, Laurel et al.

4182004 , Robichaud and Rose 2006). Nonetheless, first annulus $\delta^{18} \mathrm{O}_{\text {oto }}$ signatures were consistently

419 lower than predictions. One possible explanation is that present predictions of $\delta^{18} \mathrm{O}$ in inshore

420 habitats may have been too high as they were based on measures taken from waters deeper than

421 the fish inhabited. It is also possible that the low $\delta^{18} \mathrm{O}_{\text {oto }}$ observed reflected, at least in part, the

422 pelagic larval phase of Atlantic cod in fresher near surface waters. To test this, it would be

423 necessary to examine the $\delta^{18} \mathrm{O}_{\text {oto }}$ signatures of larval cod which has yet to be assessed in any

424 study of wild Atlantic cod.

425

426 In conclusion, the weight of the evidence provided by $\delta^{18} \mathrm{O}_{\text {oto }}$ signatures indicates that cod of the

427 founder year-class (1990) overwintering in Smith Sound in 1998, and those summering in 2000

428 in the Bonavista Corridor, were part of a single migrating group. These cod apparently

429 experienced very similar environmental conditions throughout their lives. No other group had

430 similar $\delta^{18} \mathrm{O}_{\text {oto }}$ signatures in all annuli. This conclusion is consistent with the hypothesis that the

431 Smith Sound aggregation originated from cod spawning in the Bonavista Corridor in 1990 and

432 rejoined their parent group as the Smith Sound aggregation dispersed post-2007 (Rose 1993;

433 Rose et al. 2011; Rose and Rowe 2015). Finally, an inference from the present study is that these

434 cod belong to a metapopulation (Smedbol and Wroblewski 2002, Rose et al. 2011) with farther

435 spatial expansion possible as the stock rebuilds.

436 A few comments about the implications of this study to the broader question of the population

437 structure of Northern cod are warranted. Northern cod have long been recognized as a stock 
438 complex. This term was used to describe the composite inshore and offshore overwintering and

439 spawning components that comprised the management unit (based mostly on mark-recapture

440 studies (e.g., Templeman 1962; 1979; Lear 1984). More recently, Smedbol and Wrobleski

441 (2000) modeled the sub-population structure of cod in this region as a metapopulation,

442 employing survey data spanning the range of the stock and beyond to the north (NAFO

$4432 \mathrm{GHJ} 3 \mathrm{KL}$ ). These authors reported that cod in most northerly regions (NAFO $2 \mathrm{GH}$ ) had become

444 commercially extinct prior to the declines farther south, with declines occurring progressively

445 from north to south and the most southerly region of the stock in the Bonavista Corridor

446 remaining strongest (also see Atkinson et al. 1997). Smedbol and Wroblewski (2002) predicted

447 that if the full stock was to rebuild, it would likely be by recolonization rather than local growth.

448 In a follow-up paper, Smedbol et al. (2002) stressed that their definition of a metapopulation did 449 not require local extinction, just major reduction.

451 Our data suggest that the Smith Sound cod were part of the putative Northern cod

452 metapopulation, as suggested by Rose et al. (2011). It is unlikely that this large overwintering

453 and spawning aggregation of Northern cod was entirely of local origin, and the present data

454 indicate their most likely origin was the adjacent and offshore Bonavista Corridor. The apparent

455 dispersal of the Smith Sound aggregation after 2007, in conjunction with the increase in the

456 Bonavista Corridor, further suggested that the two phenomena were related (Rose and Rowe

457 2015; Cadigan 2016). If these and the present interpretation of the spatial dynamics linking the

458 coastal area of Smith Sound and the offshore Bonavista Corridor are correct, it is apparent that

459 major changes in distribution can occur quickly. Nonetheless, the data suggest that the links were

460 there all along. Although it was not evident that onshore migration was occurring until tagging 
461 studies were initiated in 2007 (Brattey et al. 2010), the present data suggest it was taking place

462 throughout the 1990s when stock abundance was extremely low. We conclude that although

463 most of the Smith Sound cod remained in the overwintering and spawning aggregation until

464 2007, venturing out of Smith Sound along the northeast coast in summer (Brattey et al. 2010),

465 some were venturing back to the Bonavista Corridor, perhaps in search of capelin, which would

466 account for the samples taken there of 1990 year-class fish in June of 1998. As a final comment,

467 the increasing spring biomass of cod in the Bonavista Corridor after 2007 and up to 2014 (Rose

468 and Rowe 2015) is thought to enhance the likelihood of further redistribution, especially to

469 former regions of abundance to the north.

470

\section{Acknowledgments}

472 We thank S. Campana at the University of Iceland for insight and guidance in the methods

473 employed here and for reviewing a version of this MS. Thanks to the at-sea scientists and crew

474 of the Natural Sciences and Engineering Council of Canada (NSERC) Fisheries Conservation

475 Chair at Memorial University and CCGS Teleost, respectively, and Allison Pye from Memorial

476 University's Core Research Equipment \& Instrument Training (CREAIT) and Erik Pollock and

477 Lindsey Conaway from University of Arkansas's Stable Isotope Laboratory (UASIL) for

478 performing the assays. We thank Eugene Colbourne and John Brattey of the Department of

479 Fisheries and Oceans Canada for the provision of oceanographic data and otoliths as well as the

480 Marine Environmental Data Service for provision of oceanographic data. Funding was provided

481 by grants and shiptime to G.A. Rose from the Department of Fisheries and Oceans Canada, the

482 former Fisheries Products International, NSERC, the Department of Fisheries and Aquaculture

483 of Newfoundland and Labrador and the Harris Centre of Memorial University, and a Research 
484 and Development Corporation of Newfoundland and Labrador, Ocean Industries Student

485 Research Award to V. Neville.

486

487 Table 1. Age and collection information for otoliths from 1990 year-class cod used in this study 488 taken from four locations off Newfoundland.

\begin{tabular}{cccccc}
\hline & $\begin{array}{c}\text { Smith Sound } \\
\text { Winter }\end{array}$ & $\begin{array}{c}\text { Smith Sound } \\
\text { Summer }\end{array}$ & Placentia Bay & $\begin{array}{c}\text { Bonavista } \\
\text { Corridor }\end{array}$ & $\begin{array}{c}\text { Halibut } \\
\text { Channel }\end{array}$ \\
\hline \hline $\mathrm{N}$ & 14 & 19 & 10 & 20 & 24 \\
Age & 10 & 8 & 9 & 8 & 8 \\
Catch Date & Jan 2000 & June 1998 & July 1999 & June 1998 & May 1998 \\
\hline
\end{tabular}

489

490 Table 2. P-values of pair wise comparisons calculated using Tukey's post-hoc range test for

491 linear model comparing potential origin sites: Halibut Channel (HC), Bonavista Corridor (BC),

492 Placentia Bay (PB), Smith Sound Summer (SSS), Smith Sound Winter (SSW) for each otolith

493 annulus mean $\delta^{18} \mathrm{O}$. P-values with a significance of $\mathrm{p}<0.05$ are highlighted.

\begin{tabular}{|c|c|c|c|c|c|c|c|c|}
\hline \multirow{2}{*}{$\begin{array}{c}\text { Collection } \\
\text { Sites }\end{array}$} & \multicolumn{8}{|c|}{ Annulus } \\
\hline & 1 & 2 & 3 & 4 & 5 & 6 & 7 & 8 \\
\hline $\mathrm{SSW}-\mathrm{BC}$ (fig 4a) & 0.983 & 0.769 & 1.000 & 0.483 & 0.504 & 0.976 & 1.000 & 0.585 \\
\hline SSW - SSS (fig 4b) & $<0.01$ & 0.116 & 0.661 & $<0.01$ & 0.958 & $<0.01$ & $<0.01$ & $<0.01$ \\
\hline SSW - HC (fig 4c) & $<0.01$ & $<0.01$ & $<0.01$ & $<0.01$ & $<0.01$ & $<0.01$ & $<0.01$ & $<0.01$ \\
\hline SSW - PB (fig 4d) & 0.040 & $<0.01$ & 0.109 & 0.013 & 0.361 & $<0.01$ & $<0.01$ & $<0.01$ \\
\hline
\end{tabular}




\begin{tabular}{ccccccccccc} 
PB- SSS (fig 4e) & 0.658 & 0.658 & 0.599 & 0.992 & 0.634 & 1.000 & 1.000 & 0.995 \\
PB - HC (fig 4f) & 0.417 & 0.020 & $<0.01$ & 0.023 & 0.016 & $<0.01$ & 0.020 & 0.038 \\
BC- PB (fig 4g) & 0.064 & 0.079 & 0.081 & 0.285 & $<0.01$ & 0.013 & $<0.01$ & $<0.01$ \\
SSS - HC (fig 4h) & 0.989 & $<0.01$ & $<0.01$ & $<0.01$ & $<0.01$ & $<0.01$ & $<0.01$ & 0.083 \\
BC- HC (fig 4i) & $<0.01$ & $<0.01$ & $<0.01$ & $<0.01$ & $<0.01$ & $<0.01$ & $<0.01$ & $<0.01$ \\
BC- SSS (fig 4j) & $<0.01$ & 0.602 & 0.621 & 0.330 & 0.059 & $<0.01$ & $<0.01$ & $<0.01$ \\
\hline
\end{tabular}

\section{References}

496 Anderson, J.T., and Dalley, E.L. 1997. Spawning and recruitment of Northern cod as measured 497 by pelagic juvenile cod surveys following stock collapse. Can. J. Fish. Aquat. Sci. Spec. Publ. 498 54: 158-167.

499

500 Anderson, J.T., and Rose, G.A. 2001. Offshore spawning and year-class strength of northern cod 501 (2J3KL) during the fishing moratorium, 1994-1996. Can. J. Fish. Aquat. Sci. 58 (7): 1386-1394. 502 https://doi.org/10.1139/f01-068 Atkinson, D., and Sibly, R.M. 1997. Why are organisms usually bigger in colder environments?

Atkinson, D.B., Rose, G.A., Murphy, E.F., and Bishop, C.A. 1997. Distribution changes and abundance of Northern cod (Gadus morhua), 1981-1993. Can. J. Fish. Aquat. Sci. 54(S1): 132138.

Bardarson, H., McAdam, B.J., Thorsteinsson, V., Hjorleifsson, E., and Marteinsdottir, G. 2017. Otolith shape differences between ecotypes of Icelandic cod (Gadus morhua) with known migratory behavior inferred from Data Storage Tags. Can. J. Fish. Aquat. Sci. 74:2122-2130. doi: 10.1139/cjfas-2016-0307.

Begg, G.A. and Weidman, C.R. 2001. Stable $\delta^{13} \mathrm{C}$ and $\delta^{18} \mathrm{O}$ isotopes in otoliths of haddock Melanogrammus aeglefinus from the northwest Atlantic Ocean. Marine Ecology Progress Series 216: 223-233. doi:10.3354/meps216223

Bishop, C.A., Stansbury, D.E., and Murphy, E.F. 1995. An update of the stock status of Div. 2J3KL cod. DFO Atlantic Fisheries Res. Doc 95/34. 
524 Bowen, G.J. 2010. Isoscapes: Spatial pattern in isotopic biogeochemistry. Annu. Rev. Earth Planet. Sci. 38: 161-187. doi:10.1146/annurev-earth-040809-152429.

Brattey, J. 2000. Stock structure and seasonal movements of Atlantic cod (Gadus morhua) in NAFO Divs. 3KL inferred from recent tagging experiments. Canadian Stock Assessment Secretariat Res. Doc. 2000/084.

Brattey, J., and Healey, B.P. 2007. Exploitation of Atlantic cod (Gadus morhua) in NAFO Divs. 3KL: tagging results from the reopened fishery in 2006. DFO Can. Sci. Advis. Sec. Res. Doc. $2007 / 027$.

Breitenbach, S.F.M., and Bernasconi, S.M. 2011. Carbon and oxygen isotope analysis of small carbonate samples (20 to $100 \mu \mathrm{g}$ ) with a GasBench II preparation device. Rapid Communications in Mass Spectrometry 25(13): 1910-1914. doi:10.1002/rcm.5052.

Cadigan, N.G. 2016. A state-space stock assessment model for Northern cod, including underreported catches and variable natural mortality rates. Canadian Journal of Fisheries and Aquatic Sciences 73(2): 296-308. doi: 10.1139/cjfas-2015-0047

Coplen, T.B. 1995. Reporting of stable hydrogen, carbon, and oxygen isotopic abundances.

Geothermics 24(5): 707-712. doi: 10.1351/pac199466020273.

Craig, H., and Gordon, L.I. 1965. Deuterium and oxygen-18 variations in the ocean and the marine atmosphere, Lischi and Figli, Pisa, pp. 9-130.

Darnaude, A.M., Sturrock, A., Trueman, C.N., Mouillot, D., EIMF, Campana, S.E., and Hunter, E. 2014. Listening in on the past: What can otolith $\delta 180$ values really tell us about the environmental history of fishes? PLOS ONE 9(10): e108539.

deYoung, B., and Rose, G.A. 1993. On recruitment and distribution of Atlantic cod (Gadus morhua) off Newfoundland. Canadian Journal of Fisheries and Aquatic Sciences 50(12): 27292741. doi: $10.1139 / \mathrm{f} 93-298$

Epstein, S., and Mayeda, T. 1953. Variation of $\mathrm{O}^{18}$ content of water from natural sources. Geochim. Cosmochim. Acta. 4: 213-224. doi: 10.1016/0016-7037(53)90051-9 
Gao, Y., and Beamish, R.J. 2003. Stable isotopic composition of otoliths from tagged Pacific

573

574

575

576

577

578 halibut, Hippoglossus stenolepis. Environ Biol Fish 67(3): 253-261. doi: 10.1023/A:1025874110893.

Gao, Y., Joner, S.H., Svec, R.A., and Weinberg, K.L. 2004. Stable isotopic comparison in otoliths of juvenile sablefish (Anoplopoma fimbria) from waters off the Washington and Oregon coast. Fisheries Research 68(1-3): 351-360. doi: 10.1016/j.fishres.2003.11.002

Gao, Y., Schwarcz, H.P., Brand, U., and Moksness, E. 2001. Seasonal stable isotope records of otoliths from ocean-pen reared and wild cod, Gadus morhua. Environ Biol Fish 61(4): 445-453. doi: 10.1023/A:10116544

Geffen, A.J. 2012. Otolith oxygen and carbon stable isotopes in wild and laboratory-reared plaice (Pleuronectes platessa). Environ Biol Fish 95(4): 419-430. doi: 10.1007/s10641-0120033-2.

Goddard, S.V., Wroblewski, J.S., Taggart, C.T., Howse, K.A., Bailey, W.L., Kao, M.H., and Fletcher, G.L. 1994. Overwintering of adult Northern Atlantic cod (Gadus morhua) in cold inshore waters as evidenced by plasma antifreeze glycoprotein levels. Canadian Journal of Fisheries and Aquatic Sciences 51(12): 2834-2842. doi: 10.1139/f94-282.

Gotceitas, V., Fraser, S., and Brown, J.A. 1997. Use of eelgrass beds (Zostera marina) by juvenile Atlantic cod (Gadus morhua). Canadian Journal of Fisheries and Aquatic Sciences 54(6): 1306-1319. doi:10.1139/f97-033

Healey, B.P., Murphy, E.F., Brattey, J., Morgan, M.J., Maddock Parsons, D., and Vigneau, J. 2014. Assessing the status of the cod (Gadus morhua) stock in NAFO Subdivision 3Ps in 2012. DFO Can. Sci. Advis. Sec. Res. Doc. 2013/087.

Hobson, K.A., Barnett-Johnson, R., and Cerling, T. 2010. Using isoscapes to track animal migration. In Isoscapes: Understanding movement, pattern, and process on Earth through isotope mapping. Edited by J.B. West, G.J. Bowen, T.E. Dawson and K.P. Tu. Springer Netherlands, Dordrecht. pp. 273-298.

Høie, H., and Folkvord, A. 2006. Estimating the timing of growth rings in Atlantic cod otoliths using stable oxygen isotopes. Journal of Fish Biology 68(3): 826-837. doi: 0.1111/j.00221112.2006.00957.x

Høie, H., Otterlei, E., and Folkvord, A. 2004. Temperature-dependent fractionation of stable oxygen isotopes in otoliths of juvenile cod (Gadus morhua L.). ICES Journal of Marine Science 61(2): 243-251. doi: 10.1016/j.icesjms.2003.11.006. 
614 Hutchings, J.A., Myers, R.A., and Lilly, G.R. 1993. Geographic variation in the spawning of

615 Atlantic cod, Gadus morhua, in the Northwest Atlantic. Canadian Journal of Fisheries and

616 Aquatic Sciences 50(11): 2457-2467. doi:10.1139/f93-270

617

618 Jamieson, R. 2001. Environmental history of Northern cod from otolith isotopic Analysis,

619 Geology, McMaster University, Hamilton, Ontario.

620

621

Kalish, J.M. 1991. ${ }^{13} \mathrm{C}$ and ${ }^{18} \mathrm{O}$ isotopic disequilibria in fish otoliths: metabolic and kinetic

622

623

624

625

626

627

628

629

630

631

632

633 effects. Marine Ecology Progress Series 75: 191-203.

Kastelle, C., Helser, T., McKay, J., and Anderl, D. 2014 Poster. Age validation of Pacific cod (Gadus macrocephalus) using stable oxygen isotopes $\left(\delta^{18} \mathrm{O}\right)$ In Western Groundfish Conference (18th), Victoria, B.C.

Kastelle, C., Helser T., McKay, J.L., Johnston C., Anderl D., Matta M., Nichol D. .2017. Age validation of Pacific cod (Gadus macrocephalus) using high-resolution stable oxygen isotope $\left(\delta^{18} \mathrm{O}\right)$ chronologies in otoliths. Fish Res 185: 43-53.

Knickle, D.C., and Rose, G.A. 2010. Seasonal spawning and wind-regulated retention-dispersal of early life stage Atlantic cod (Gadus morhua) in a Newfoundland fjord. Fisheries Oceanography 19(5): 397-411. doi: 10.1111/j.1365-2419.2010.00553.x

Laurel, B.J., Gregory, R.S., Brown, J.A., Hancock, J., and Schneider, D. 2004. Behaviour consequences of density-dependent habitat use in marine fish. Marine Ecology Progress Series 272: $257-270$.

Lawson, G.L., and Rose, G.A. 2000. Seasonal distribution and movements of coastal cod (Gadus morhua L.) in Placentia Bay, Newfoundland. Fisheries Research 49(1): 61-75. doi:10.1016/S0165-7836(00)00187-9.

654 Northwest Atlantic Fishery Science 5: 143-159.

Lear, W.H. 1986. The stock complex of Atlantic cod (Gadus morhua) in NAFO Divisions 2J, 3K and 3L. NAFO SCR Doc. 86/32. oxygen isotopes measured by high-precision secondary ion mass spectrometry reflect life history of a yellowfin sole (Limanda aspera). Rapid Communications in Mass Spectrometry 27(6): 691699. doi: $10.1002 / \mathrm{rcm} .6502$. 
660 Robichaud, D., and Rose, G.A. 2006. Density-dependent distribution of demersal juvenile Atlantic cod (Gadus morhua) in Placentia Bay, Newfoundland. ICES Journal of Marine Science 63(4): 766-774. doi:10.1016/j.icesjms.2005.12.002.

Rose, G.A. 1993. Cod spawning on a migration highway in the north-west Atlantic. Nature 366(6454): 458-461. doi: 10.1038/366458a0.

Rose, G.A. 2003. Monitoring coastal Northern cod: towards an optimal survey of Smith Sound,

Rose, G.A. 2005. Capelin (Mallotus villosus) distribution and climate: a sea "canary" for marine ecosystem change. ICES Journal of Marine Science 62(7): 1524-1530. doi: 10.1016/j.icesjms.2005.05.008.

Rose, G.A. 2007. Cod: the ecological history of the North Atlantic fisheries. Breakwater Books Ltd., St. John's, NL.

Rose, G.A. 2009. Variations in the target strength of Atlantic cod during vertical migration. ICES Journal of Marine Science 66(6): 1205-1211. 10.1093/icesjms/fsp085.

Rose, G.A., Atkinson, B.A., Baird, J., Bishop, C.A., and Kulka, D.W. 1994. Changes in distribution of Atlantic cod and thermal variations in Newfoundland waters, 1980-1992. ICES Mar. Sci. Symp. 198: 542-552.

Rose, G.A., deYoung, B., Kulka, D.W., Goddard, S.V., and Fletcher, G.L. 2000. Distribution shifts and overfishing the Northern cod (Gadus morhua): a view from the ocean. Canadian Journal of Fisheries and Aquatic Sciences 57(3): 644-663. doi.org/10.1139/f00-004.

Rose, G.A., and Kulka, D.W. 1999. Hyperaggregation of fish and fisheries: how catch-per-uniteffort increased as the Northern cod (Gadus morhua) declined. Canadian Journal of Fisheries and Aquatic Sciences 56(S1): 118-127. 10.1139/f99-207.

Rose, G.A., Nelson, R.J., and Mello, L.G.S. 2011. Isolation or metapopulation: whence and whither the Smith Sound cod? Canadian Journal of Fisheries and Aquatic Sciences 68(1): 152169. doi.org/10.1139/f10-135.

Rose, G.A., and Rowe, S. 2015. Northern cod comeback. Canadian Journal of Fisheries and Aquatic Sciences: 1789-1798. doi:10.1139/cjfas-2015-0346

Ruzzante, D.E., Taggart, C.T., Doyle, R.W., and Cook, D. 2001. Stability in the historical pattern of genetic structure of Newfoundland cod (Gadus morhua) despite the catastrophic decline in population size from 1964 to 1994. Conserv Genet 2(3): 257-269.

Shephard, S., Trueman, C., Rickaby, R., and Rogan, E. 2007. Juvenile life history of NE Atlantic 
705

706

707

708

709

710

711

712

713

714

715

716

717

718

719

720

721

722

723

724

725

726

727

728

729

730

731

732

733

734

735

736

737

738

739

740

741

742

743

744

745

746

747

748

749

orange roughy from otolith stable isotopes. Deep Sea Research Part I: Oceanographic Research Papers 54(8): 1221-1230. doi: 10.1016/j.dsr.2007.05.007

Smedbol, R.K., and Wroblewski, J.S. 1997. Evidence for inshore spawning of Northern Atlantic cod (Gadus morhua) in Trinity Bay, Newfoundland, 1991-1993. Canadian Journal of Fisheries and Aquatic Sciences 54(S1): 177-186. doi: 10.1139/f96-146.

Stanley, R.R.E., DiBacco, C., Thorrold, S.R., Snelgrove, P.V.R., Morris, C.J., Gregory, R.S., Campana, S.E., and Bradbury, I.R. 2016. Regional variation in otolith geochemistry of juvenile Atlantic cod (Gadus morhua) in coastal Newfoundland. Canadian Journal of Fisheries and Aquatic Sciences 73(10): 1507-1519. doi:10.1139/cjfas-2015-0353

Stanley, R.R.E., Bradbury, I.R., DiBacco, C., Snelgrove, P.V.R., Thorrold, S.R., and Killen, S.S. 2015. Environmentally mediated trends in otolith composition of juvenile Atlantic cod (Gadus morhua). ICES Journal of Marine Science 72(8): 2350-2363. doi: 10.1093/icesjms/fsv070

Tan, F.C., and Strain, P.M. 1988. Stable isotope studies in the Gulf of St. Lawrence. In Chemical oceanography in the Gulf of St. Lawrence. Edited by P.M. Strain. Department of Fisheries and Oceans. Canadian Bulletin of Fisheries and Aquatic Sciences, Ottawa, ON. pp. 59-77.

Team, R.C. 2014. R: A language and environment for statistical computing. In R Foundation for Statistical Computing, Vienna, Austria.

Templeman, W. 1979. Migrations and intermingling of stocks of Atlantic cod, Gadus morhua, of the Newfoundland and adjacent areas from tagging 1962-1966. Int. Comm. Northwest Atl. Fish. Res. Bull. 14: 5-50

Templeman, W. 1962. Divisions of cod stocks in the Northwest Atlantic. ICNAF Redbook, III, pp. 79-123.

Templeman, W., and Fleming, A.M. 1956. The Bonavista longlining experiment, 1950-1953. Bull. Fish. Res. Board Can 109.

Weidman, C.R., and Millner, R. 2000. High-resolution stable isotope records from North Atlantic cod. Fisheries Research 46(1-3): 327-342.

Wroblewski, J.S., Kulka, D.W., Narayanan, S., Oake, A.M., Collier, A.G., and McGrath, B.D. 1995. Winter distribution and movements of Northern Atlantic cod (Gadus morhua) along the Newfoundland-Labrador continental shelf edge derived from observations on commercial trawlers. Fisheries Oceanography 4(2): 128-146. doi: 10.1111/j.1365-2419.1995.tb00067.x.

Wurster, C.M., Patterson, W.P., and Cheatham, M.M. 1999. Advances in micromilling techniques: a new apparatus for acquiring high-resolution oxygen and carbon stable isotope values and major/minor elemental ratios from accretionary carbonate. Comput. Geosci. 25(10):1159-1166. doi: 10.1016/s0098-3004(99)00052-7. 


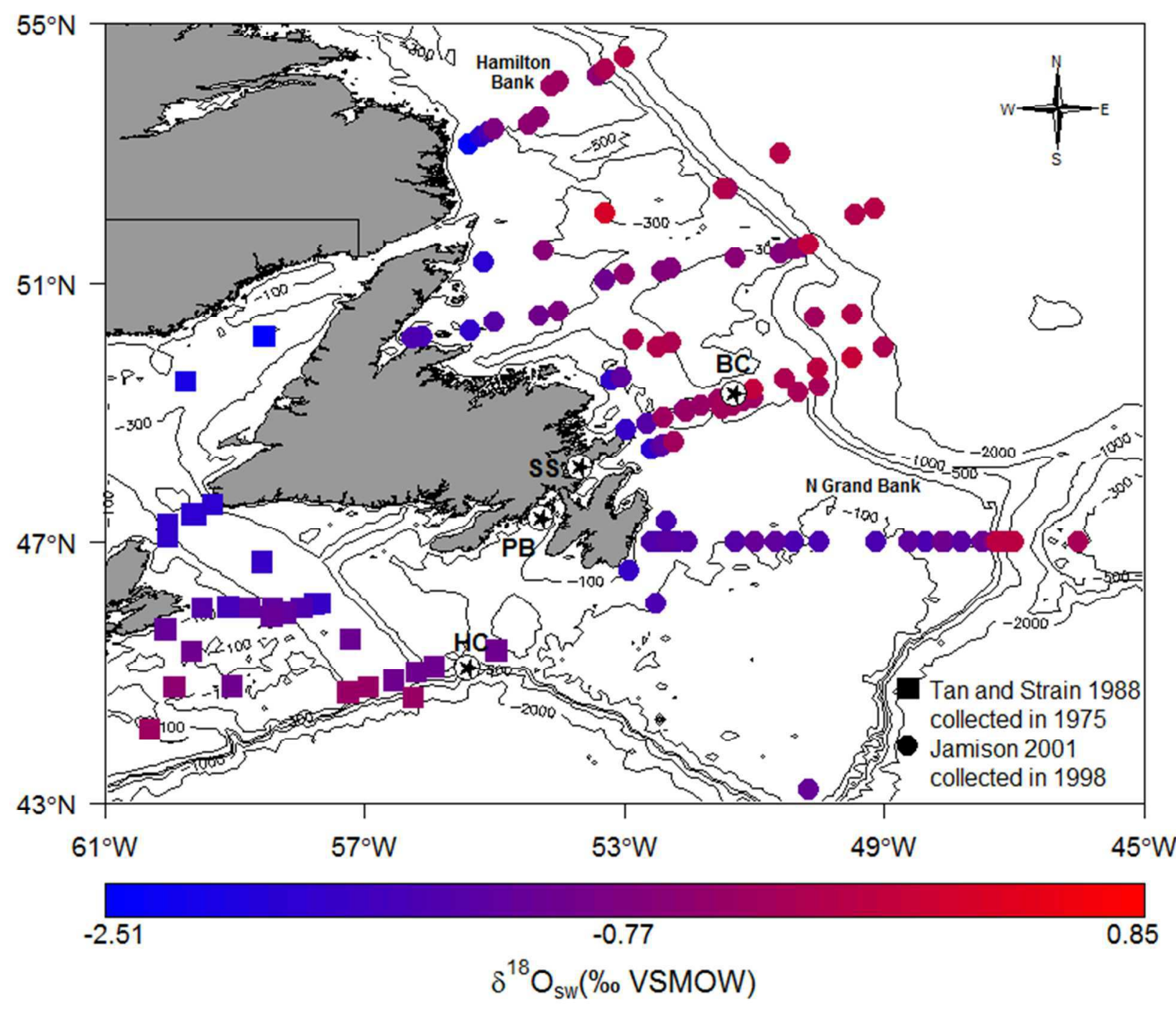

Figure 1. $\delta^{18} \mathrm{O}_{\mathrm{sw}}$ (\% VSMOW) gradients on Newfoundland and Labrador shelves shown as a range of colour from blue to red. Circles represent seafloor bottom data from Jamieson (2001), and squares represent seafloor bottom data from Tan and Strain (1988). Stars indicate the collection locations for Atlantic cod in this study: Bonavista Corridor (BC), Halibut Channel (HC), Placentia Bay (PB) and Smith Sound (SS). Map data (C2018 R package "mapdata" and accompanying "worldhires" function. 


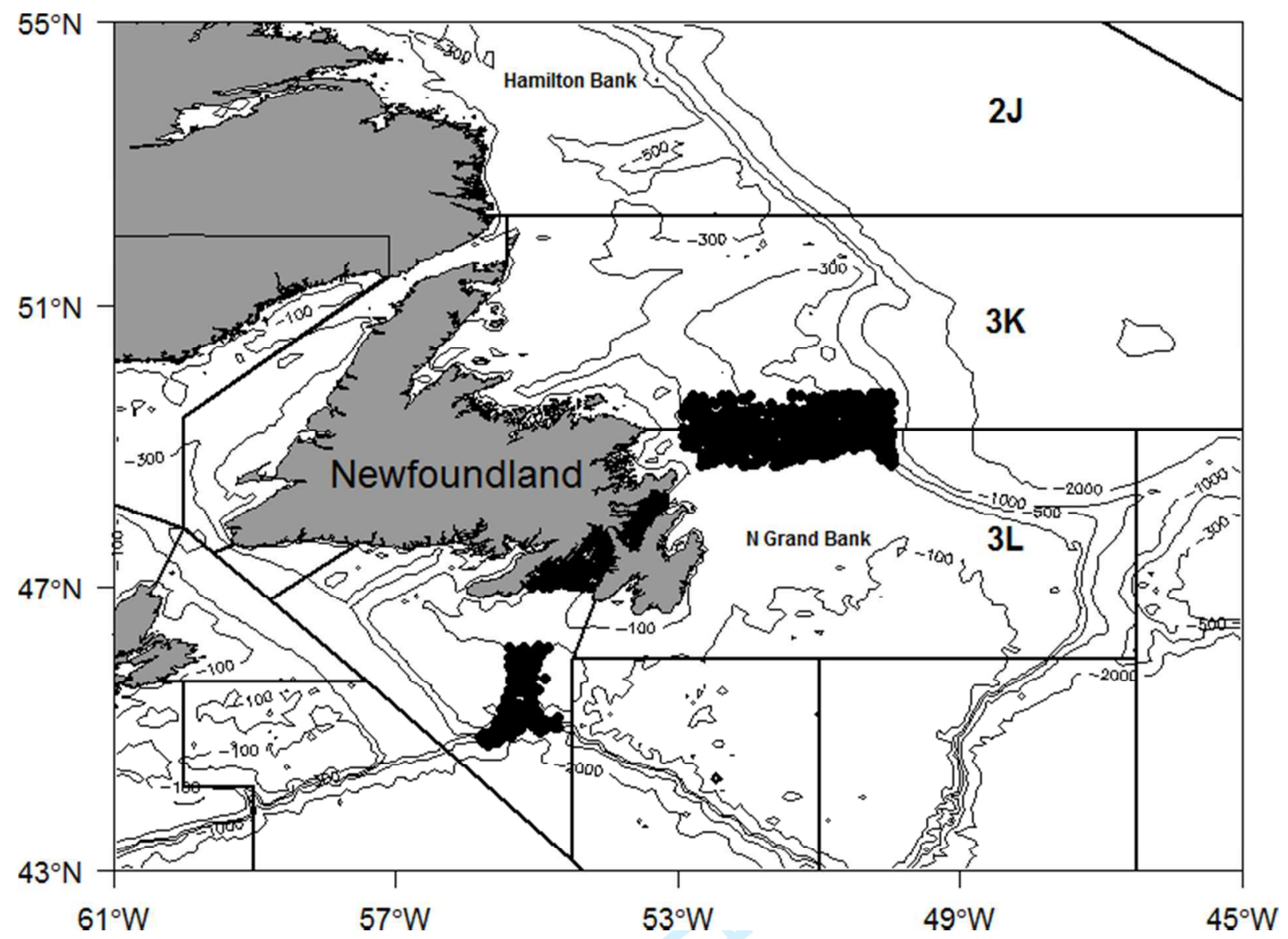

Figure 2. Hydrographic data taken from the Marine Environmental Data Service (MEDS) to calculate predicted $\delta^{18} \mathrm{O}_{\text {oto. }}$. Map data $@ 2018 \mathrm{R}$ package "mapdata" and accompanying "worldhires" function. 


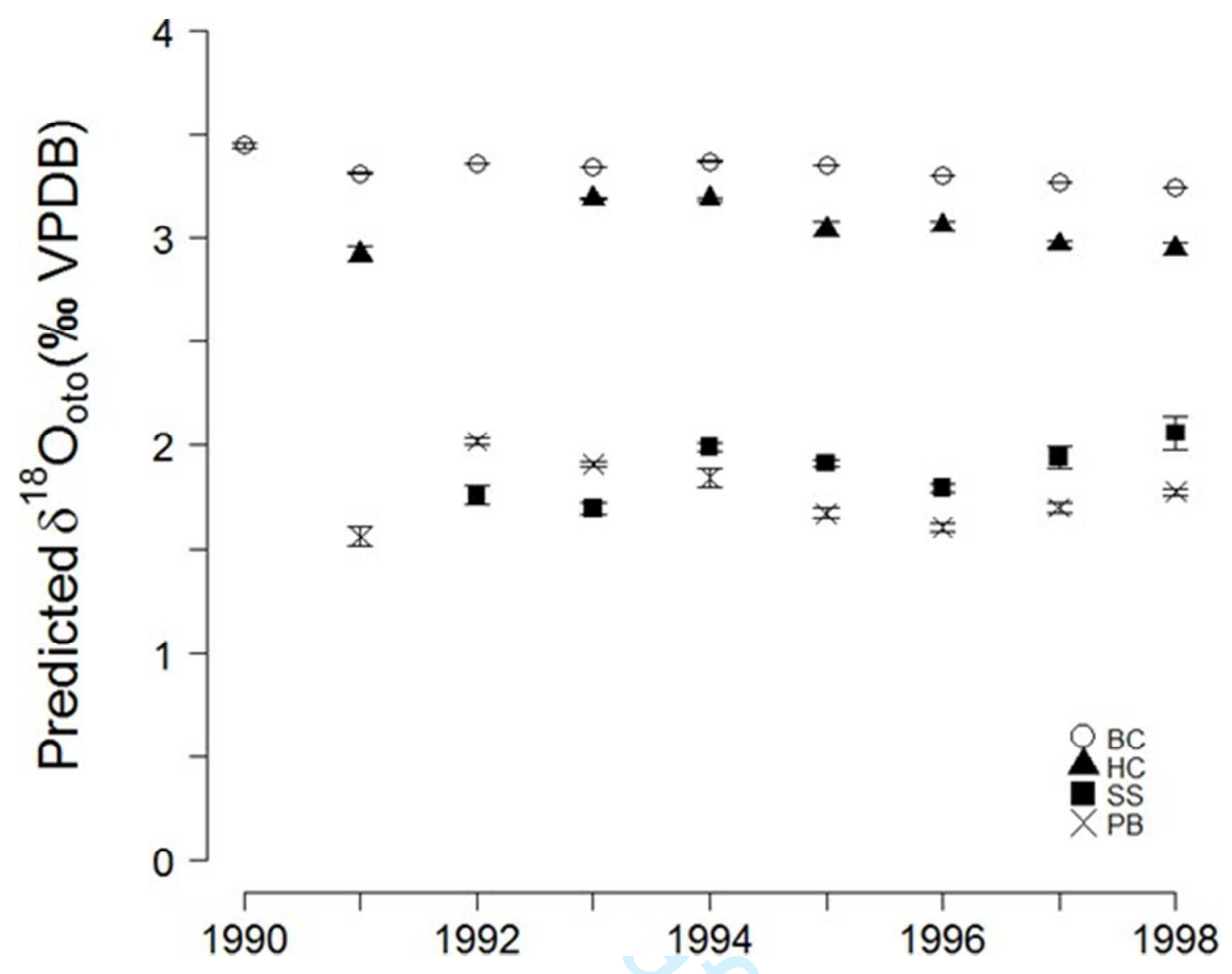

Figure 3. Mean predicted $\delta^{18} \mathrm{O}_{\text {oto }}$ for Atlantic cod inhabiting Smith Sound (filled squares), Bonavista Corridor (open circles), Placentia Bay (x's) and Halibut Channel (filled triangles). Error bars represent 95\% confidence intervals. 

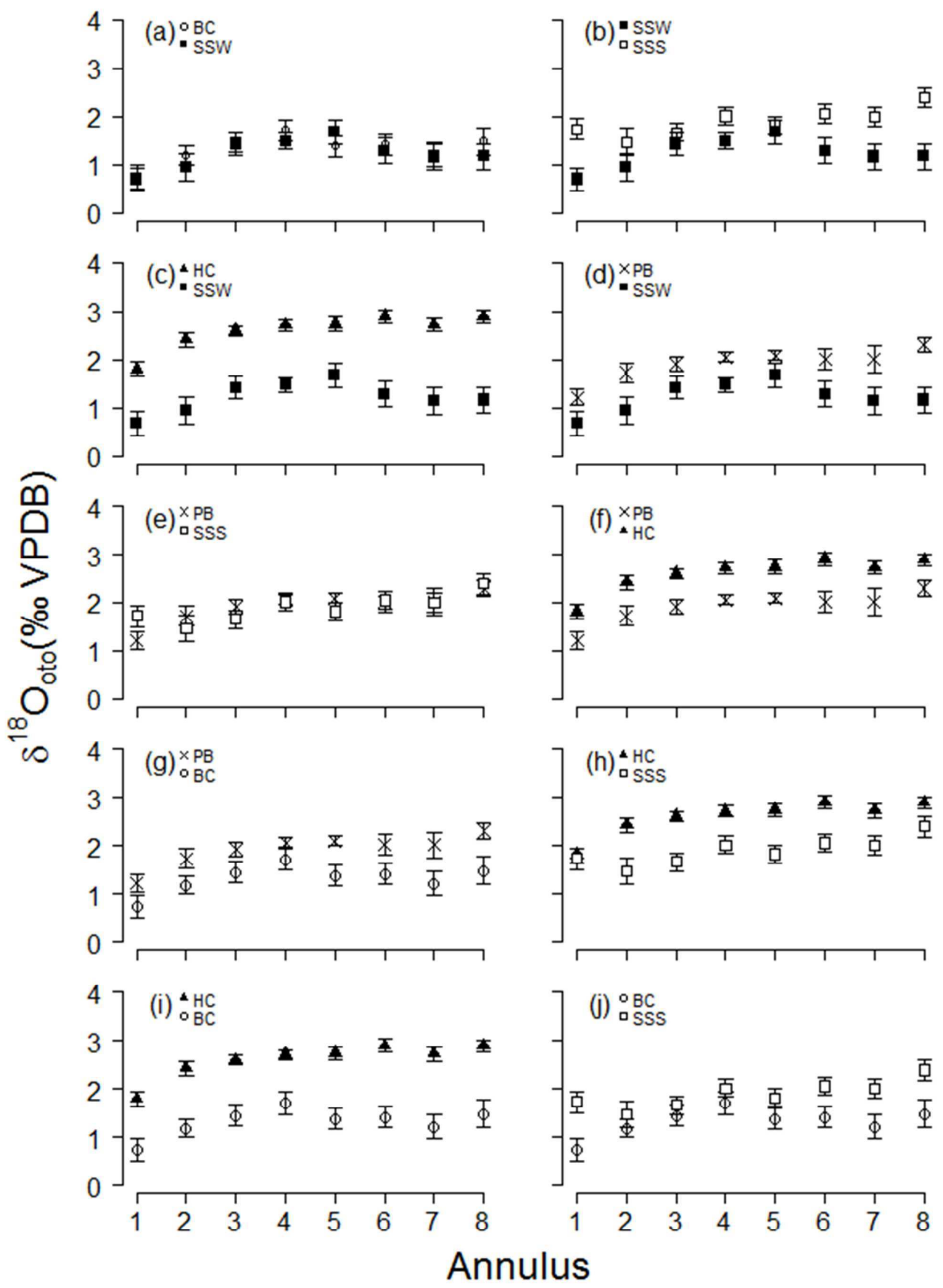

Figure 4. Mean $\delta^{18} \mathrm{O}_{\text {oto }}$ signatures of Atlantic cod comparing Smith Sound Winter (SSW; filled squares), Smith Sound Summer (SSS; open squares) Halibut Channel (HC; filled triangles),

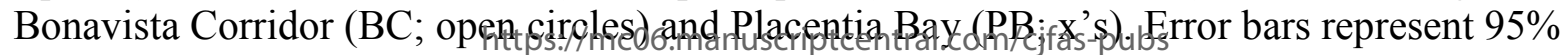
confidence intervals. a) BC and SSW, b) SSW and SSS, c) HC and SSW, d) PB and SSW, e) PB 
and SSS, f) PB and $\mathrm{HC}, \mathrm{g}$ ) PB and $\mathrm{BC}, \mathrm{h}$ ) $\mathrm{HC}$ and SSS, i) $\mathrm{HC}$ and $\mathrm{BC}$ and J) $\mathrm{BC}$ and SSS. 

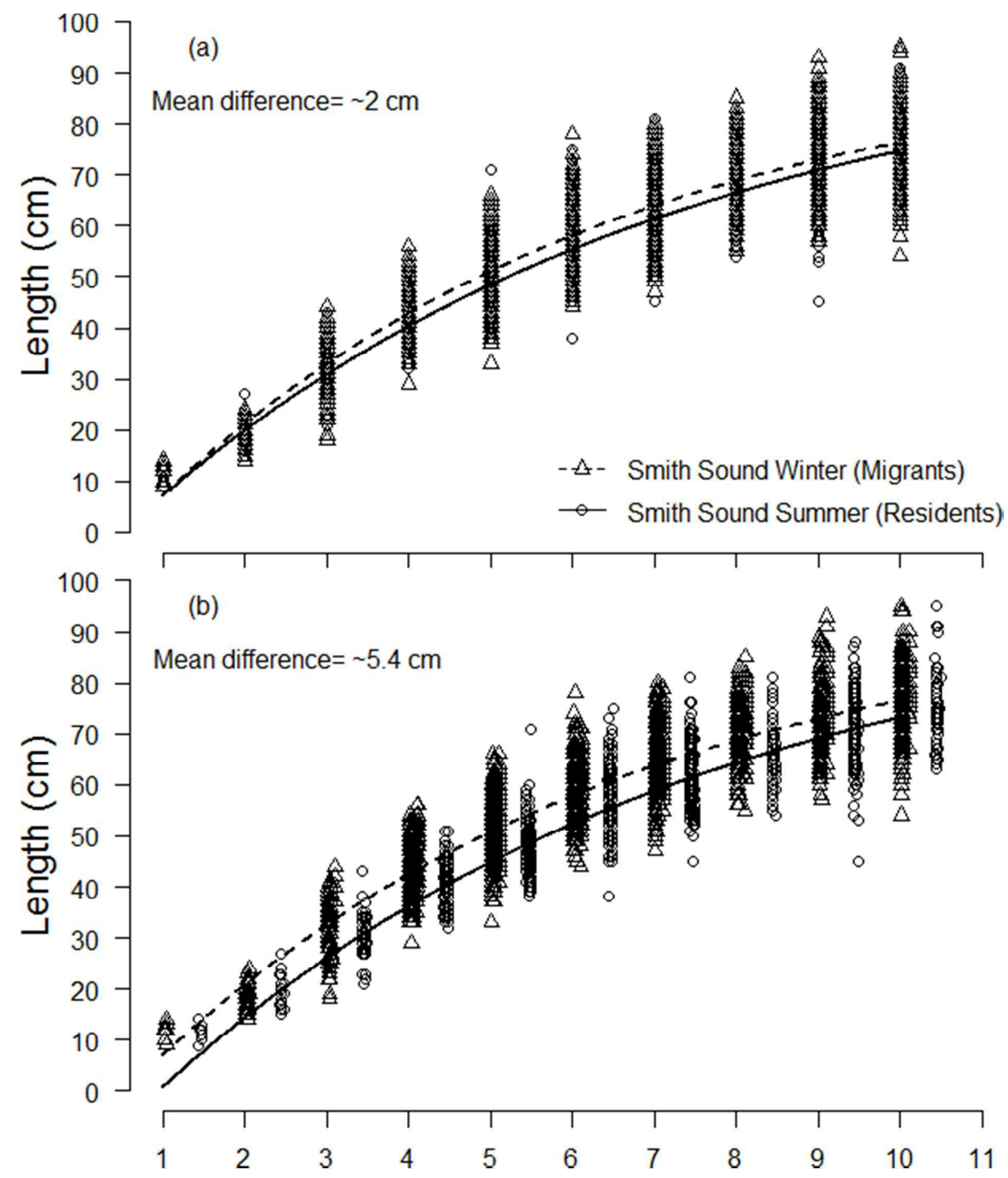

Figure 5. Length-at-age and fitted von Bertalanffy curves for overwintering (January-February samples, triangles) and resident Smith Sound cod (June, circles). a) Cod captured in January June were treated as the same age b) corrected for intra-annual differences in age. 